\title{
Afghanaid
}

\section{REHABILITATION PROGRAMME IN THE PANJSHIR VALLEY}

MONITORING MISSION:AUGUST 1991

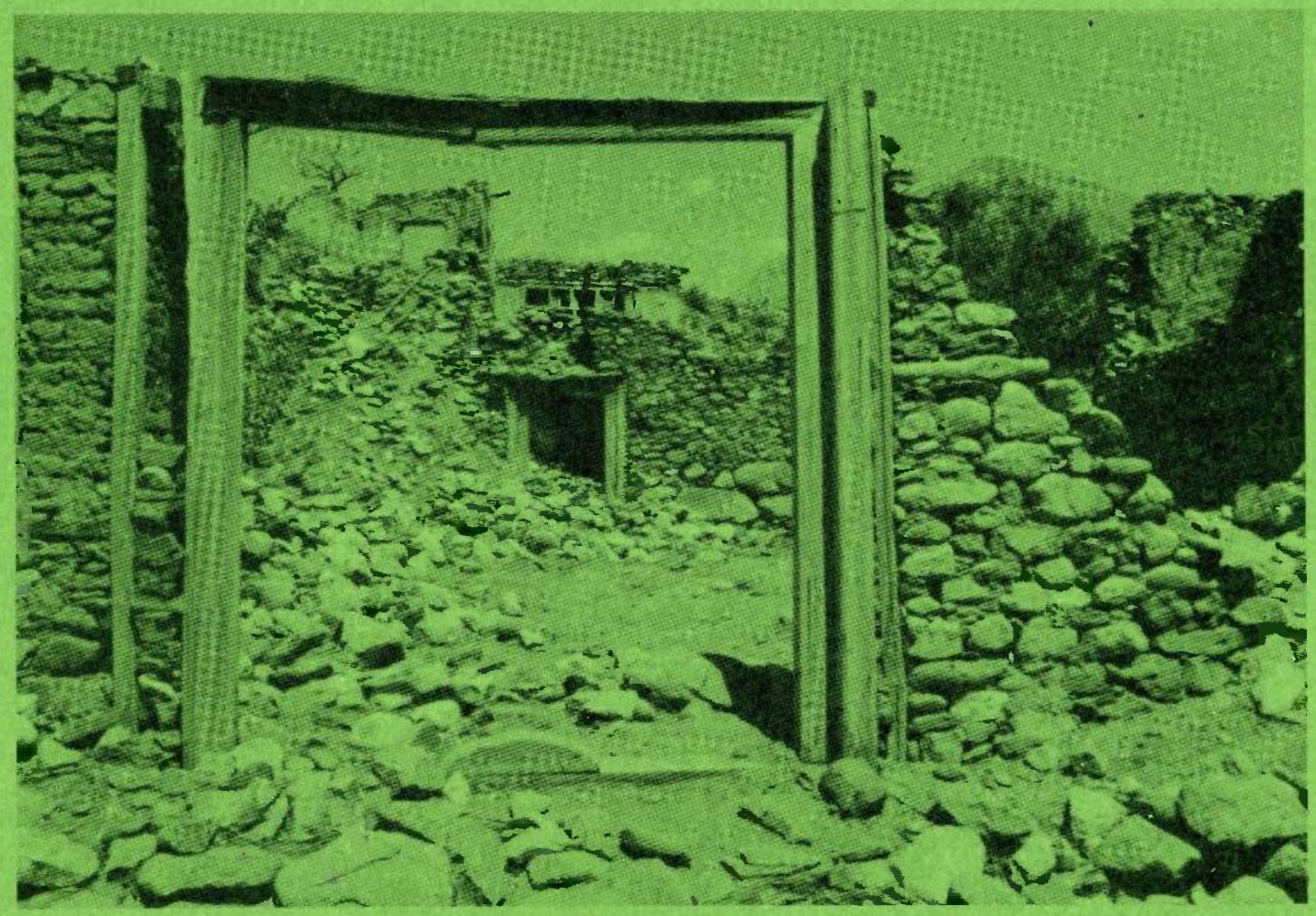




\section{REHABILITATION PFOGRAMME}

\section{IN THE}

PANJSHIR VALLEY

MONITORING MISSION: AUGUST 1991

Report prepared by: Mark Pont 


\section{CONTENTS}

\section{Page}

Preface

Summary

Map of Panjshir Valley

1.0 Introduction

2.0 Objectives

3.0 General situation

CURRENT AND FORMER PROJECTS

4.0 Update on former projects

5.0 Timber tree projects

6.0 Fruit tree project

PROPOSED PROJECTS AND RECOMMENDATIONS

7.0 Tree project recommendations

8.0 Improved wheat seed

9.0 Agricultural chemicals 9

10.0 Machinery $\quad 10$

11.0 Irrigation 11

12.0 Proposed bridges at Rokha and Tawakh 15

13.0 Rokha Hospital water supply 16

14.0 Salangi refugees 17

15.0 Laghmani refugees 19

$\begin{array}{ll}16.0 & \text { Earthquake damage }\end{array}$

$\begin{array}{lll}17.0 & \text { Conclusions } & 20\end{array}$

Appendix Sample prices in Gulbahar bazaar 
Afghanistan has for many years ranked among the poorest countries in the world; more than a decade of war has had a disastrous effect on the country and its people. A quarter of the country's villages has been destroyed, agricultural production has been more than halved, and five million Afghans have fled their country as: refugees. Almost half of the world's total number of refugees are Afghan.

Afghanaid is a registered charity which was set up in 1983. It is committed to the long and difficult process of helping the Afghan people to rebuild their country. Its principal aim is to contribute to rural rehabilitation through agricultural and irrigation projects. These are to enable refugees to return to their land and to allow those who have remained in the countryside to regain their economic independence.

With a head office in London and a field office in Peshawar, Pakistan, Afghanaid works at village level with Afghan communities providing expertise, training and assistance. The agency maintains a flexibility to respond to the frequent emergencies which affect Afghanistan. Afghanaid also operates a cross-border ambulance programme together with a tailoring project for disabled Afghan refugees in Peshawar.

HEAD OFFICE

Afghanaid

292 Pentonvilie Road

London

N1 $9 N R$

United Kingdom

Te1: (071) 2782832

Fax: (071) 8378155
FIELD OFFICE

Afghanaid

5-B Gulmohar Road

University Town

Peshawar NWPF

Pakistan

Tel: (521) $42030 / 42322$

Fax: (521) 42322

\section{ACKNOWLEDGEMENTS}

Front cover photograph: Destroyed houses at Astana, August 1991 Photograph by M: Pont (c) Afghanaid 1992 


\section{SUMMARY}

1. The Afghanaid monitoring team, consisting of the project officer for the area and an independent monitor, spent 15 cays in the Panjshir valley of Kapisa province in August 1991.

2. The team had two objectives. The first was to assess the results of Afghanaid's 1990 seed multiplication programme and emergency food project, and the progress of two 1991 proje ts establishment of timber tree nurseries and the distribution of fruit tree cuttings. The second objective was to identify future potential project activities.

3. The 1990 seed multiplication programme had been successfu1, as in 1989. The farmers were extremely pleased with the improved seed and displayed a clear understanding of its value in comparison with the local varieties.

4. The Laghman refugee emergency feeding programme was also deemed to have been a success, on the basis of interviews with a number of refugee families.

5. The timber tree project was not executed as planned, with one large nursery being establish, as opposed to a number of smaller ones. The nursery was, however, well laid out and maintained.

6. The fruit tree distribution had been successful. The cuttings were, however, planted late and only approximately 80 percent of them survived.

7. Due to heavy infestation of crops by weeds, a need was identified for the initiation of a chemical weed control programme.

8. The restoration of six irrigation systems in $f i v e$ different areas of the valley was seen as offering scope for increasing agricultural productivity in the areas concerned.

9. The only road through the valley was observed to hale two sections that would be blocked in the spring by flood wate-. In order to ensure that this road remains open, allowing und is upted access to markets throughout the year, the construction of two bridges would be required.

10. The hospital at Rokha was seen to require the provision of a clean drinking water supply, the present one being inadequete and unhygienic.

11. The salangi refugees displaced to the area around Jabul Saraj, at the bottom of the Panjshir valley, and in the vicinity of charikar require food assistance, the number of families in extreme need being about one thousand. 


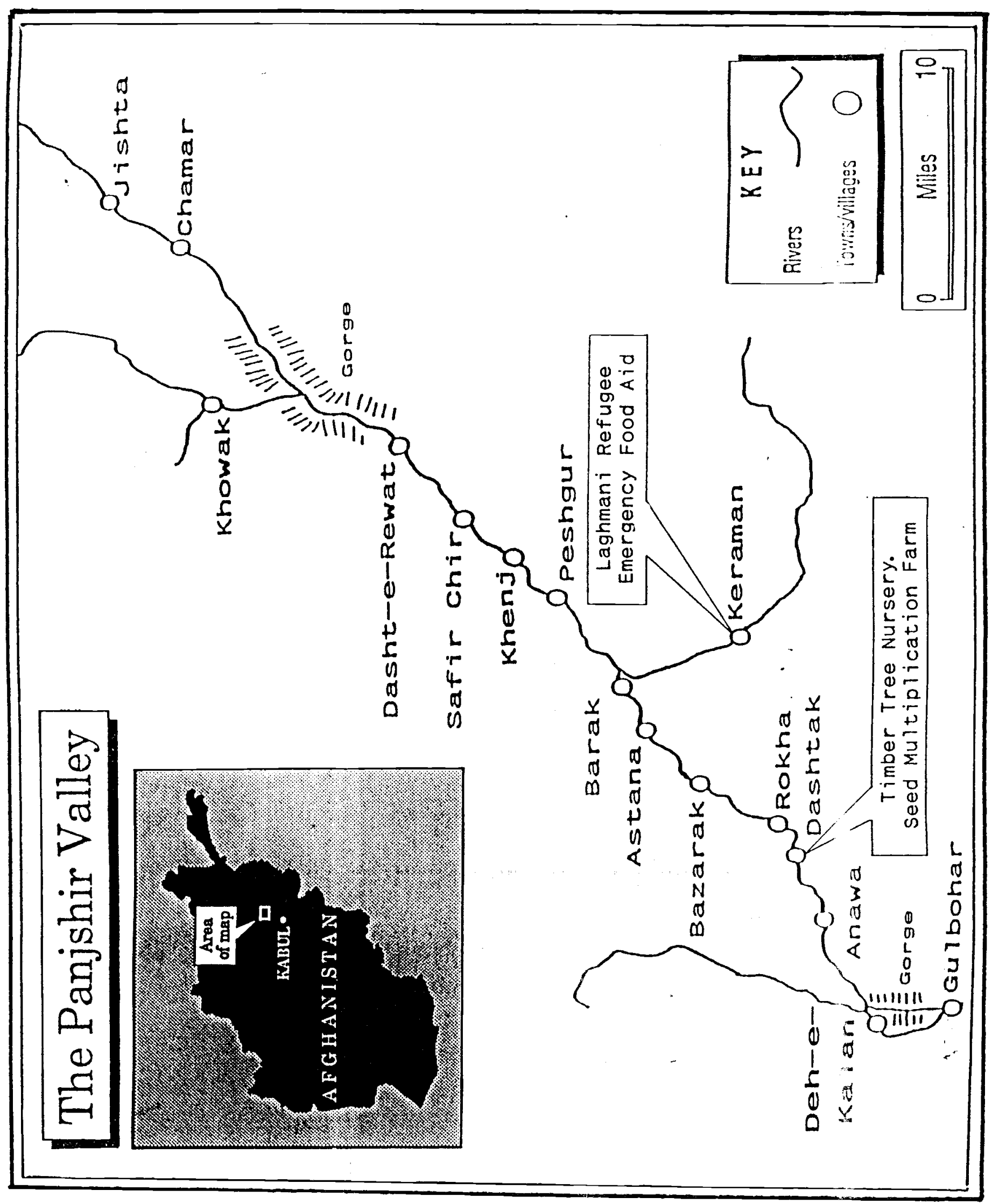


1.1 The Panjshir valley is situated in Kapisa province in northeast Afghanistan. The valley was 1 argely depopulated and most of its villages destroyed in some of the most destructive fighting of the Afghan war. Soviet and Afghan government forces left the Panjshir in the spring of 1988. Since that time the valley has been at peace, and refugees, mostly internally displaced, have been returning in increasing numbers.

1.2 Afghanaid began providing emergency assistance to the Panjshir in 1985 with a cash-for-food programme for internal refugees. In subsequent years assistance was increased, with greater emphasis given to support for reconstruction work. The cleaning and repair of irrigation channels and the distribution of improved wheat seed and fertiliser were among the chief projects carried out in addition to the original cash-for-food programme.

1.3 Afghanaid field teams oversee ali projects in the valley. In addition, the expatriate project officer and monitors $v i s i t$ the area at regular intervals. A general report on the agricultural and political situation was made in 1988 following the soviet and Afghan government withdrawal ("Repatriation and Reconstruction, Northeast Afghanistan, 1988-89"). Two further reports on Aghanaid's projects in the Panjshir were prepared in 1989 and one report was prepared in 1990, following visits by expatriate monitors.

1.4 This report is the result of a monitoring mission to the valley in August 1991. The expatriate project officer and an expatriate monitor, assisted by a translator, spent 15 days in the Panjshir with two Afghanaid fieldworkers who had spent most of the previous several months carrying out Afghanaid projects there. The monitor had previously visited the Panjshir and prepared reports on Afghanaid's Panjshir projects in 1989 and 1990 .

\subsection{OBJECTIVES}

2.1 The objectives of the mission were as follows:

i. to assess the results of the 1991 timber tree froject for the provision of 40,000 rootstocks to provide roof timbers;

ii. to assess the results of the 1991 fruit tree froject for the provision of 10,000 fruit tree saplings;

iit. to assess the need for emergency assistance reclested for Laghmani refugees in Darra-e-Hazara, Salangi refugees in Gulbahar, and those affected by the eartinuake of February 991 ;

iv. to assess in overall terms Aighanaid's ongoing work in the Panjshir and to recommend areas or specific projects for ruture assistance. 
3.1 Conditions in the Panjshir continued to show overal "* improvement compared with earlier years.

3.2 At the time of the monitor's visit, the wheat crop had been harvested in the lower valley, while the harvest was still uriderway in the middle valley and had not yet begun in Paryan, the uppermost section of the valley. In general, farmers in the lower valley reported a good harvest.

3.3 The return of refugees to their villages has been continuing this summer and the rebuilding of houses is progressing slowly throughout the valley. Refugees are returning from Kabul and provinces north of the Hindu Kush (especially Takhar, Bishlan, Kunduz and $\mathrm{Ba} / \mathrm{kh}$ ). In addition, refugees are reported to be returning from Pakistan this year.

3.4 No precise figures on the numbers of refugees return ing are available. Officials of the local Shura-e-Nazar administration estimate very roughly that 75-80 per cent of the valley's pre-war population is now living there. Residents and commanders of villages along the main road generally report that about half the pre-war number of families are now resident in their areas. In villages away from the road however, a smaller proportion of seople left as refugees.

3.5 Life in the Panjshir is relatively secure as there has been no fighting or bombing there since government forces left in May 1988. During periods of fighting in northeastern Afghanistan this summer however, government jets have flown over the valley regularly on their way to bombing missions in Badakhshan. The nearest government presence is the garrison of Jabal saraj, guarding the Salang highway where it enters the Hindu-kush near Gulbahar at the mouth of the Panjshir valley.

3.6 Travel and trade between Kabul and Mujahideen-controlled areas appears to have increased over the past year. Gulbahar bazaar, the Panjshir's chief supply centre at the valley's mouth, has grown considerably, with many new shops appearing in the past twelve months. Shopkeepers buy goods in Kabul and pay bribes at government checkposts to bring them into Mujahideen territory. Privately operated passenger vehicles travel daily from the Panjshir to Kabul and back. (Men of military age however, are not permitted to pass government checkposts unless they have comleted their military service.)

3.7 Fighting between supporters of Hezb-e-Islami Afgho istan (Hekmatyar) and Jamiat-e-Islami Afghanistan in Andarak, the neighbouring valley immediately to the north of the Parishir, caused some tension in the area in the autumn of 1990. This fighting ended last year and Andarab has been quiet since.

3.8 Tension between Jamiat-e-Islami and Hezb-e-islami (Hekmatyar) in the neighbouring province of Laghman caused an 
iniflux of refugees into the Panjshir side valley of Darra-e-Hazara two years ago. The current situation of these Laghmani refugees is. discussed in section 15.

3.9 Another internal refugee problem, that of refugees from valleys along the Salang highway, is discussed in section 14 .

3.10 The earthquake which shook much of northeastern Afghanistan in February 1991 caused some damage in the Panjshir. This is discussed in section 16 .

3.11 An extension of the main Panjshir road being constructed in the upper valley towards the Anjuman Pass has not progressed significantly since last autumn. Motor vehicles travel as far as the village of Jishta in Paryan. This road is being built by the local Construction Committee of the Shura-e-Nazar.

3.12 A road funded by VITA was completed last year up the side valley of Darra-e-Hazara. Large sections of this road were washed away in this year's very heavy spring floods. At the time of the monitor's visit, vehicle access to any part of Darra was impossible.

3.13 The main Panjshir road is still in very poor condition. The unusually heavy spring rains had caused flooding of the main road near shaba this summer, making the road impassable by vehicle when the monitor arrived, until the river level had subsided. The Construction Committee has recently been given two bulldozers by a United Nations agency, which are to be used for road improvements.

3.14 The number of private vehicles in the Panjshir has increased substantially since last year. People of the prosperous emerald-mining villages of Khenj, Safed Chir and Dasht-e-Rewat in the middle valley have bought large numbers of private jeeps in the past year. Two years ago there were only two jeeps in the entire valley.

3.15 Rebuilding of houses is progressing throughout the valley, but the vast majority of houses are still in ruins from years of fighting and neglect: No accurate figures exist, but the monitor estimates from sight that roughly 70-80 per cent of the vailey's houses are wholly or partially ruined. Most villages which were destroyed and abandoned now have only a handful of fully repaired houses among piles of rubble or partially destroyed houses ir which families occupy a few repaired rooms. Exceptions to this are the villages of Khenj, Safed Chir and Dasht-e-Rewat whose ganeral prosperity has enabled the rebuilding of nearly all their houses. Paryan, the upper valley, is more sparsely populated and suffered relatively little damage from bombing and dispersal of its population. 
4.1 The Panjshir's Construction Committee (then called the Reconstruction Committee) allocated money from Afghanaid funds donated in 1988 to construct a vehicle bridge over a tributary stream of the Panjshir River at Peshghur in the middle valley. The construction of this bridge was delayed for various reasons, among them the difficulty of getting concrete of the required strength, until the summer of 1990 .

4.2 The bridge was completed in the autumn of 1990, successfully weathered the heavy spring floods of 1991 and was seen to be in good condition by the Afghanaid team in August 1991. It is a single concrete span between two side supports of stone and concrete.

4.3 The Peshghur bridge has improved the traffic flow up and down the valley during periods of high water.

4.4 Afghanaid funds given in 1988 were also used to construct single-span vehicle bridges at Safed Chir, Shaba and Qabzan (near Rokha). All bridges were seen to be in good condition.

4.5 Afghanaid funds given in 1988 were used by the Construction Committee to repair a clinic at safed chir and a school at Changaram (Changaran).

4.6 The clinic at safed Chir has been demolished and a new clinic was seen under construction on the same site by the monitor. The construction of the new clinic is being financed by the world Health Organisation (WHO) through the Peshawar-based Consultant Bureau for Reconstruction (CBR).

4.7 The school building at Changaram has been used as a clinic since 1989 by a group of Arab doctors. A new clinic was seen under construction next to the school building. Construction of the new clinic is also being financed by the WHO through the CBR. (The WHO is financing the construction of three clinics in the Panjshir this year. )

4.8 When the new building at Changaram is completec, the Construction Committee's intention is to house the Arab doctors' clinic in it, so that the school building can then be used as a school once more.

\subsection{TIMBER TREE PROJECTS}

5.1 In February 1991" Afghanaid sent the Reconstriction Committee's representative in Peshawar a letter of intent regsrding the purchase of 40,000 timber tree saplings, including the propod 
budget for the programme. The head of the Agricultural Committee in the Panjshir was subsequently instructed to purchase 40,000 timber. cuttings.

5.2 The trees were purchased in the Ghorband area of Parwan province by the committee, in collaboration with the Afghanaid field team, and transported to the Dashtak farm in the lower Panjshir, where they were planted on twenty jeribs of 1 and. The intention was to establish a timber tree nursery under the committee's control.

\subsection{FRUIT TREE PROJECT}

6.1 In February 1991 Afghanaid sent a similar letter of intent regarding the purchase of 10,000 fruit tree saplings. This letter also included the proposed budget for the programme. The head of the Shura-e-Nazar's Agricultural Committee in the Panjshir was subsequently instructed to purchase the saplings

6.2 The trees were purchased in the Ghorband area of Parwan province by the committee, in collaboration with the Afghanaid field team, and transported to the Panjshir Valley.

6.3 As envisaged in the letter of intent, the trees were distributed throughout the valley in batches of ten trees per farmer. Greater numbers were distributed to farmers who had previously owned larger orchards. In this distribution approximately one hundred farmers fell into this category.

6.4 Due to the price of the saplings being lower than budgeted 11,390 saplings were actually purchased and distributed to 973 farmers in the upper, middle and lower Panjshir.

6.5 Nine of these sites were visited. Eighty percent of the trees were seen to be healthy. The other twenty percent had died. The death of these trees was ascribed to their late arrival at the planting site. A proportion of them had already sprouted prior to planting.

6.6 In one location serious caterpillar damage was in evidence. The Agricultural Committee agreed to undertake a spraying programme to deal with such problems, to be carried out by its crop Protection Department.

6.7 In another location an orchard that had received one hundred trees was found to be totally neglected, due to the owner having been summoned to Taloqan by Commander Masood. Yar Mohammed, head of the Agricultural Committee, agreed that larger orchards, such as this one, if neglected. in this manner would be tended by the committee staff. 
7.0 TREE PROJECT RECOMMENDATIONS

7.1

Fruit Trees

7.1.1 The fruit tree programme initiated eartier this year may be deemed a success considering the constraints under which t was implemented. There is however further need for fruit trees in the valley.

7.1.2 This need can be addressed in the short term by the purchase and distribution of a further 10,000 saplings. In the long term it would be more beneficial to set up a fruit tree nursery alongside the timber tree nursery at the Dashtak farni. This could be used as a feeder for other smaller nurseries and for general distribution.

7.1.3 Great emphasis should be placed on the 10,000 saplings and the cuttings from the nursery being used to re-establish old nurseries and, where necessary, to establish new ones. In this way the process of creating a self-sustaining industry may be started.

\subsection{Timber Trees}

7.2.1 The timber tree nursery set up this year can, if dealt with correctly, become a large scale feeder for the rest of the valley. There should be no need for the further purchasing of trees.

7.2.2 The root stock in the nursey has an average of four cuttings per plant. The 40,000 trees should therefore produce approximate $7 y$ 160,000 cuttings for distribution before the zoming spring.

7.2.3 There are three major recommendations for their use: (a) setting up or re-establishing nurseries along the length of the valley, (b) planting them along the main irrigation channels to help tie in the retaining walls, and (c) planting them alorg the farmers' minor irrigation channels as was done in the past.

7.2.4 The first of these is the most important in the long term. setting up or re-establishing nurseries is an essential element in producing a self-sustaining timber tree production system. If the main feeder nursery at Dashtak fails, these smaller, widelydistributed ones will be able, after one or two years, to continue the process of feeding the valley with timber trees.

7.2.5 Concerning the second recommendation, one of the major problems affecting irrigation channels in the valley is collapse of the retaining walls, due firstly to erosion and, to a lesser degree, to neglect. The establishment of trees along these channels wijl help tie in the retaining walls as the roots bind into and reinforce the walls. This follows standard practise as seen in other areas where a spacing of one tree per metre along minor irrigation channe $1 \mathrm{~s}$ is common. 
7.2.6 The third recommendation would follow common practice among farmers prior to the war, when timder trees were planted along minor irrigation channels, due to lack of available area on the main agricultural 1 and.

\subsection{IMPROVED WHEAT SEED}

8.1 The wheat seed programme this year will receive no certified seed from Pakistan. The Agricultural Committee farm at Dashtak should have a yield of approximately 10 MT this year. A11 of this seed will be treated with $V$ itavax and be redistributed by the committee, in conjunction with the Afghanaid field team, to approximately three hundred farmers throughout the valley.

8.2 Fertiliser will be supplied in the correct quantities to each of the recipients, according to the ratio of one unit of DAP and 1.5 units of urea per unit of seed.

8.3 The Agricultural Committee will be asked by Afghanaid to purchase back $10 \mathrm{MT}$ of Pak 81 from the farmers for redistribution. This seed will also be treated with Vitavax and suppliec with fertiliser according to the ratio given above.

8.4 This programme should reach approximately six hindred beneficiaries.

\subsection{AGRICULTURAL CHEMICALS}

9.1 In the Panjshir this year one of the main prolems affecting with the wheat crop was weeds. The worst of these was wild oats. Many of the fields were so heavily infested with it, that it was almost impossible to identify that they were ir fact planted to wheat.

9.2 Sheaves of wheat from harvested fields showed that the oats were harvested along with the wheat. The seed to be resown would thus have a higher percentage wild oats infestation than the previous crop, due to the multiplication factor involved with seed production. The level of infestation may increase exponentialiy as a result of this factor.

9.3 In the case of Pak 81 where the seed is generally resown over the local seed, the presence of wild oats in the seed sample could invalidate the use of the sample as a high yielding one.

9.4 It is therefore recommended that only fields planted to Pak 81 be treated. This should help to produce purer seed samples for further multiplication. It will be impossible to identify 411 of these fields. It should be possible however to identify 2,000 jeribs of 1 and sown with Pak 81 .

9.5 The fruit trees have been damaged by both insect and fungal diseases. Funds were allocated in the fruit tree budget for 
chemical protection. A further allocation should be considered for the coming year.

9.6 The timber trees have been damaged by both insects and fungal diseases. There was no allocation in the timber tree budget for chemical protection. A budget should be considered for this year and the coming year, depending on requirements.

9.7 The Crop Protection Department of the Agriclitural Committee at present has 23 knapsack sprayers for a 13 mar team. In order to be able to carry out the recommended crop protection programme, it will probably be necessary to increase the size of this team to 23 , to utilise fully the sprayers available.

\subsection{MACHINERY}

10.1 The most important item requested in this category was threshers. At present there are only two threshers (of the power take-off kind, run off tractors) in the entire valley, one bought with Afghanaid funds, the other by the Shura-e-Nazar. Both of these were manufactured in Pakistan, but purchased in Kabul. They are the first ever used in the valley. Both were located in the lower valley. All the way up to the middle valley farmers had brought their wheat crop near to the road waiting for the threshers to arrive.

10.2 Providing a further two threshers would give a cərtain amount of flexibility to their use. At present the machines are only able to thresh the crops on the side of the river on whish the road runs. Were another two threshers provided, making a trtal of four, it would be possible to locate them on the bridgtseads, enabling farmers on both sides of the river to have access tc them. The bridges across the river tend to be located opposite the villages and larger areas of agricultural land.

10.3 The harvest dates become later the further the croos are planted up the valley. It would therefore be possible to follow the harvest up the valley, moving from bridgehead to bridgehead.

10.4 At present there are only two Russian 'Belarus' tractors in the area, both provided by the Swedish Committee for Afghanistan. The provision of further tractors and threshers will not undermine private sectors activities, as these two tractors and the two threshers are under the control of the Agricultural Committee.

10.5 Were another two threshers to be provided, they would also be under the control of the Agricultural committee. One unit of four threshers would be much easier to establish a working system for, than two units of two threshers each, under different control.

10.6 The, practicalities of using self-powered threshers hould also be investigated. "They do not generai y have the same th oughput as power take-ofif threshers and they nay not be availabie in 
Kabu1. Their use would however obviate the need for the plrchase of tractors.

10.7 Self-powered reapers were also requested. These resemble a scaled-down version of a combine harvester's cutter bar (blade). This is attached to a pair of wheels, a motor and a set of handlebars for the operator to grasp. They are very versatile and can be used as easily on small plots of land as on larger fields. They are manufactured by Batala Industries in the Punjab area of Pakistan, but are as yet unavailable in kabul. If these were to be provided they would have to be transported to the area by local traders from Pakistan via Kabul.

10.8 The use of such reapers would significantiy reduce the time and labour required for harvest. This would result in the earlier release of both the 1 and and the labour for cultivation for the following crop.

10.9 The reapers may be used for cutting both wheat and maize. The time saved could be used to ensure adequate cultivation prior to the wheat being sown. This in turn should help in the reciction of the weed infestation problem that afficts such a large proportion of the wheat cropping areas.

10.10 There are however potential problems with such a system. The present system is labour intensive and the reaping season is one of the few times of the year when the poorer people of an area can rely on getting some sort of work. The use of reapers could affect the 1 ivelihood of these sectors of society. As the raapers are made in Pakistan there could be serious difficulty in obtaining spare parts, which might prove prohibitively expensive.

\subsection{IRRIGATION}

11.1 The Panjshir's system of traditional irrigation was devastated by bombing and neglect during nearly a decade of fighting. Many channels have been cleaned and repaired as people have returned to the valley and begun to restore their 1 and to use. No firm figures are available as to the proportion of the pre-war irrigation system which has been restored so far, but the local administration estimates that some 60 per cent of channels are now in use. This estimate is supported by the team's observations.

11.2 Afghanaid has provided funding in the past for the cleaning and repair of irrigation channels. The restoration of local irrigation is an important factor in encouraging refugees to return to their villages and land.

11.3 The Construction Committee is frequently asked by local people to repair or improve irrigation channels and their headworks. The team informed Engineer Amiruddin, head cf the Construction Committee, that money might be available this year, or subsequently, to repair channels which would bring abandone $i$ land back into cultivation and encourage the return of refugee fam? lies. 
11.4 Four channels suggested by Engineer Amiruddir. were inspected by the monitor in 1990 and recommended for cleaning.: (Cf. Afghanaid report, "Rehabilitation Programme in the Panjshir Valley; Monitoring Mission: October 1990", pp. 25-26.) No money rias been made available to date.

11.5 These four channeis were inspected again this year, as were two other large areas of fields with insufficient irrigation, at Astana and Tawakh.

11.6 The team asked Engineer Amiruddin to provide Afghanaid with further details on al1 the areas and channels inspected, specifying the length of channels to be cleaned, the number of jeribs they irrigate, the number of families who would benefit from restoration of the channe1, etc. A brief description of each channel or area follows.

\section{ASTANA}

11.7 Before the war 100 families lived in the main viliage of Astana. Now some 40 families 1 ive in repaired rooms amicit the rubble of destroyed houses. In 1989 Afghanaid funded the cleaning of Astana channel, which irrigates the lower fields of this viliage. A large area of fields has since been returred to cultivation as a result. Many terraced fields above this channel however remain virtually without water.

11.8 Two short karezes in a gully above the village feed water into a stream from which the upper terraces were formerly irr gated through a network of ten main distributor channels. The water flow now is insufficient as the karezes have not been cleaned for many years and are partially blocked. As a result most of the terraced fields remain uncultivated.

11.9 The cleaning of the two karezes and the channel network would provide enough water to return this substantial area of terraced fields to full cultivation. In addition it would encourage absent villagers to return and rebuild their houses.

\section{RAHMANKHEL}

11.10 In 1990, the Afghanaid monitor inspected Sata channel in the upper part of Rahmankhel village (near Bazarak). When the monitoring team returned to see the channel this year, some men of the village pointed out a higher channel, sahib channel, which they said it would be more useful to repair. Sata channel branches off Sahib channel near the water source in the side valley of Parandeh, but the higher channel is now completely dry. Although restoring Sahib channel would involve more work than the restoration 0 sata channel, it would be worthwhile because of the greater a:ea it would irrigate.

11.11 The full restioration of the lowe: channe1 (Sata channe1) would involve the construction of a short section of concrete where a tank has damaged its original course. 
11.12 Two channels inspected by the monitor last year at. Rokha were examined again this year - Qazikhei and Darzakhel channels. Both take water from a small tributary of the Panjshir river on the northeast side of Rokha village.

11.13 Information on these two channels provided in the 1990 monitoring report is still relevant and is reproduced here. (A11 statistics are rough estimates. Accurate survey details are to be provided by the Construction Committee.)

a) Qazikhel channe1: length, perhaps $6 \mathrm{~km}$ (including two distributor branches); would irrigate perhaps 100 jeribs, comprising 1 and of 5 villages. This channel, which irrigates an area formerly occupied by a soviet military base, was partially cleaned in 1989. It needs further work as it carries very ittle water in its lower reaches, where the stone retaining walls were dismantled to provide building material for the base. There is some danger from anti-personnel mines here.

b) Darzakhel channe 1: length; about $4.5 \mathrm{~km}$; would irrigate about 300 jeribs. This channel, feeding from the same stream as Qazikhel channel, once watered an expanse of hillside supporting many smal1 terraces of fruit trees, al1 now dead from lack of water. About 45 families would benefit from the cleaning and improvement of this channel.

\section{JANGALAK}

11.14 Another channel inspected last year and recommendod for possible restoration is Jangalak channel (also called Bazarak channel). This was inspected again this year. The village of Jangalak (near Bazarak bazaar), still iargely deserted and in ruins, would benefit from the restoration of this channel but the team decided that other channels should be given priority since there is already some water available in Jangalak from a higher channel, Nawalij channel. Nawalij channel was cleaned with Afghanaid funds in 1989. The upper part of Jangalak channel was also cleaned with Afghanaid funds in 1989 , but not as far as Jangalak village.

\section{TAWAKH}

11.15 Tawakh village, some distance below Rokha, includes a large area of several hundred jeribs of terraced fields, irriga cd in varying degrees from several springs within and above the vi:lage, and from a tributary of the Panjshir river. The monitor had asked about this area of poorly irrigated 1 and and was taken to i:ispect it.

11.16 The fields and terraces close to the village and water sources receive an adequate supply of whter for double-croping. Terraces further from the water sources receive only enough water to grow a single crop. Apparently this has always been the case, 
but the team was told that the overall supply of water is iess than before the war because some of the springs have become partially. blocked and require cieaning.

11.17 Cleaning the springs, opening un one or two possible new springs, and cleaning and enlarging the main irrigation channels would provide a greater overall supply of water for Tawakh. This would provide more water for the further terraces, along a number of channels which appear to have fallen into disuse. It might provide sufficient water for some of these further terraces to be double-cropped although this is uncertain without more detailed information.

11.18 It was decided that a more detailed survey of the area would be necessary before a decision could be taken as to the necessity or suitability of work being undertaken there by Afghanaid. Accordingly, the Afghanaid field team arid the Construction committee were asked to make a further assessment of the area and to send the results to the Afghanaid off ce in Peshawar.

\section{GULBAHAR}

11.19 The Agricultural Committee and the construction Conmittee had mentioned Gulbahar as a possible site for irrigation work. After visiting areas around Gulbahar, the general assessme:t was that the agricultural situation was sufficiently good that Gulibahar could not be considered a priority area for Afghanaid assistance.

11.20 Since emergency aid had been requested for salangi refugees in the Gulbahar area however, the team inspected the headworks of four irrigation channels as possible sites for a cash- or foot-forwork project.

11.21 The intakes of the four irrigation channels (Lakar, Waziri, Deh-e-Bala, and Ishmael channels) take water from the Shutul River where it enters the plain at Gulbahar. A stone and concrete intake was built for Lakar channel in 1989 with Afghanaid funds. Repair work was also done on Waziri and Deh-e-Bala channels in the same year.

11.22 Al1 four irrigation channels are in use but the Construction committee wants to build stone and concrete headiorks for two channels which currently have readworks of loose stone only. In addition, some repairing of leaks and strengthening of retaining walls is advisable.

11.23 This repair work would not normally warrant Afg.anaid funding, but it might be considered for the sake of provicing a cash- or food-for-work project for some ct the salangi refug ses in Gulbahar. Engineer Amiruddin of the Construction Committee was asked to provide further details on the improvements intendad for these channels to enable Afghanaid to rach a decision or this possibility. 
11.24 See also section 14 on Salangi refugees.

DARA-E-DUSDAN

11.25 Dara-e-Dusdan is an area above the road north of the Dashtak farm. Two streams descend separate valleys and converge into one larger one. They apparently carry an adequate quantity of water for the proposed site to be irrigated. In the summer one is completely subterranean, while the other is reduced to a comparative trickle but is also reported to have underground water flow.

11.26 The proposal is to dam the two streams to collect the water during summer, so that at the critical irrigation times there is adequate water for the 500 jeribs that have been proposed for irrigation.

11.27 Constructing such a reservoir will require a considerable outlay of money. It must therefore be fully justified pricr to implementation.

11.28 One possible justification relates to the situation of the present Agricultural Committee farm at Dashtak, which is in danger of being reclaimed by the owner who is at present in Kabul. Were this farm to be reclaimed it could jeopardise a number of the programmes which are being run there: improved seed multiplication, the timber tree nursery, crop trials, and the proposed fruit tree nursery.

11.29 The Afghanaid team was informed by the Agricultural Committee that the 7 and at Dara-e-Dusdan was unowned. The reason given was that the land was uncultivable.

11.30 If by the construction of an irrigation reservoir these 500 jeribs were to be irrigated and cultivation made possible, a number of longer term activities would be made more feasible. In addition to this, longer term security could be provided for activities presentiy carried out on the Dashtak farm, by the provision of an alternative site.

\subsection{PROPOSED BRIDGES AT ROKHA AND TAWAKH}

12.1 In the past Afghanaid has funded the construction of small single-span concrete vehicle bridges at Safed Chir, Peshghur, Shaba and Qabzan. These have eased road communications significan iy in the valley, particularly during periods of high water in the spring and early summer.

12.2 Engineer Amiruddin of the Construction Committee asked if Afghanaid assistance might be available for the building of two further bridges over small tributary streams at Rokha and Tawakh. currentiy streams flow across the main Panjshir road at both places. The flow of water causes little problem through most of 
the year but during the heavy spring floods this year, both streams proved very difficult to cross for vehicles and foot traffic.

12.3 In both Rokha and Tawakh it would be possible to build a smal1 bridge similar to those mentioned in Paragraph 12.1. The latter would be preferable. Such a bridge would consist of a single concrete slab on two supports of stone and concrete.

12.4 The team examined the proposed sites for both bridges. They told Engineer Amiruddin that although Afghanaid gave priority to irrigation and other agricultural projects, it was pussible that money might be available, probably for one bridge rather than for two.

12.5 If money is available for ons bridge only, the Rokra site was judged to be the more important of the two because of the greater volume of water there and because of its location in an area of relatively dense population. (Rokha is the largest bazaar of the lower valiey.)

\subsection{ROKHA HOSPITAL WATER SUPPLY}

13.1 Rokha Hospital is the main hospital in the Panjshir valley. (There is one other hospital at Anawa (Anaba), in addition to several clinics throughout the valley.) In addition to a daily intake of civilian patients, the hospital regularly treats wounded Mujahideen and those injured by anti-personnel mines and other ordnance scattered about the valiey. The Panjshir orthopaedic Workshop, established by the Sandy Gal1 Afghanistan Appeal in 1990, is located on the same site.

13.2 The monitors had been informed of the inadequacy of Rokha Hospital's water supply. While visiting the hospital they inspected the water supply to determine whether improvements might be effected within the Afghanaid assistance programme.

13.3 The nearest supply of clean water is a spring about one mile $(1.6 \mathrm{~km})$ from the hospital. Because of the time required to bring water from the spring, water is often taken from a sma 11 "sardaba" (covered 'spring or other water source) within the hospital grounds. The sardaba's water is muddy and unclear as it is filled by a small stream which flows along a footpath and through a sma 11 marsh where cattle sometimes graze. The hospital's toilets, emptying into an open cesspit, are located withi\% four yards (four metres) of the sardaba.

13.4 The most practical means of supplying clean water to the hospital would be to instal1 a pipe from the spring of clean vater. A pump would not be required as the spring is at a higher elevation than the hospital.

13.5 The team examined the spring and concluded that it could be used for a piped water supply for the hospital. To ensure a clean supply a concrete casing with a removable cover could be 
constructed around the spring. This casing would require one short pipe to provide water for several local families who regulariy use: the spring and a second, main pipe leading to the hospital.

13.6 The hospital pipe would probably have to be placed underground to avoid freezing in wilter. The constriction Committee said it would provide estimates both for the cost of installing an underground pipe and for one aboveground.

13.7 The local families who use the spring said they would have no objection to its being used to supply the hospital.

13.8 The hospital authorities were told that the possibility of giving assistance in this matter would be discussed in Pestawar.

\subsection{SALANGI REFUGEES}

14.1 Prior to the final departure of Soviet troops from Kabul in 1989, villages along the Salang highway through the Hindu Kush were destroyed and cleared of their inhabitants. These families were forced to seek refuge elsewhere. Some. went to Kabul, Andarab and other areas, but many went to Gulbahar and Jabal Saraj districts, near the mouth of the Panjshir valley. (Afghanaid distributed emergency funds to affected families in the Salang valleys in 1989 following the destruction of their villages.)

14.2 Most of those affected were the inhabitants of three valleys adjacent to the Salang highway: Darra-e-Rast, Koglami and Orati.

14.3 Most Salangi refugee families in Gulbahar are ir very difficult circumstances. Few have any money, there is 1 ittls paid employment available in the area and they are forced to iive in the houses of friends or other local people.

14.4 Many Salangi refugees have been asking local commande "s for assistance this year. In addition to those in the Gulbahar and Jabal Saraj area, Salangi families still living in the upper valleys near the Salang Pass have been walking to Gulbahar (a twoday journey) to seek assistance.

14.5 The Kabul government prevents those who have 1 and or suses in the military zone along the highway from entering it, anc food and other supplies must be carried on foot or pack animals tirough the mountains from Gulbahar. In addition there has been finting between the government and Mujahideen along the highway in recent months, leading to further difficulties for those local peop $ə$ who have stayed in their valleys.

14.6 The Shura-e-Nazar's overall commander for Parwan and western Kapisa provinces is Commander Fazal Ahmad Azimi. He told the team that there were about 3,000 families of salangi refugees (about 21,000 people) in Gulbahar and Jabal Saraj districts. In 
addition, he said, there were about 1,000 families still lixing in the Darra-e-Rast, Koglami and Orati.

14.7 Commander Azimi's recent predecessor, Commander Bismillah, had drawn up a list of the 1,000 neediest salangi families. Commander Azimi told the monitor that the Agricultural Cornittee would be able to provide Afghanaid with a copy of this list if required.

14.8 Some Salangi families received 5,000 afghanis in assistance last winter. This was distributed by the commanders from funds supplied by the Swedish Committee for Afghanistan.

14.9 The team interviewed members of 12 salangi families in the houses where they were living near Gulbahar. One family had jought a house to live in, but al1 the others 1 ived in rooms lent to them by relatives or local strangers. None of the heads of families had a regular job, though most said they did occasional labouring work when it was available. There is little work available in the area however. Most families had young children. Those children seen were obviously poorly nourished, as indeed were the majority of the adults.

14.10 While the monitor was meeting Commander Azimi an old man arrived from Koglami valley near the Salang highway. He had walked for five days to ask for assistance from the commander because his family, he said, had no food to eat. The team was told that salangis in a similar position came asking for help daily.

14.11 Some Salangis have managed to find employment in Gulbahar bazaar, while a few had some private resources when they came to the area. The conclusion however, is that the great majority of Salangi refugees are in a very difficult financial position. All those interviewed said they needed only one thing: money for food, or food itseif.

14.12 If Afghanaid decides to make emergency funds available to heip a proportion of the Salangi refugees, it could be distributed in kind rather than cash, in a programme similar to that organised last winter to assist Laghmani refugees in Darra-e-Hazara.

14.13 Food- or cash-for-work projects could also be organised. Four irrigation channels taking water from the Shutul River near Gulbahar were inspected. They were suggested by the constriction Committee as possible sites for such a project. (See Parajraphs 11.19-24.)

14.14 The work which the Construction Committee wishes to complete on these channels might provide work for a maximum of four teams of 15 men each for one month or so, depending on how much work is to be done. Assuming each workman supports one family, this work would be a valuable input of cash or food benefitting some 420-480 people. (The local Shura-e-Nazar commander assumes an average of 7 people per family. The 12 Salangi families interviewed by the Afghanaid teám in fact averaged 7.9 people per family.) 
14.15 The Construction Committee was asked to provide more detailed information on the work they wish to complete on the. Shutul channels to enable Afghanaid to reach a decision on the feasibility of a food- or cash-for work project.

\subsection{LAGHMANI REFUGEES}

15.1 Large numbers of Laghmani refugees have come into the side valley of Darra-e-Hazara in 1990 and 1991. These refugees, supporters of Jamiat-e-Islami Afghanistan, left because of fighting between themselves and Laghmani supporters of Hezb-e-Islami Afghanistan (Hekmatyar).

15.2 The Shura-e-Nazar has been concerned to help these Laghmani refugees since their return to their lands in the Alishing district of Laghman at present could bring a renewal of Hezb-Jamiat rivalry in Laghman.

15.3 The Shura-e-Nazar has arranged rooms for most of the Laghmani refugees in the houses of local people in Darra or in the houses of refugees absent in Pakistan, Kabul or elsewhere. In addition the shura provides the Laghmanis with monthly food rations.

15.4 In the spring of 1991 Afghanaid provided blankets and a four-month supply of food rations for a total of 190 Laghmani refugee families (975 people).

15.5 In september 1990 a survey carried out under the auspices of Engineer Yar Mohammed Noori (head of the Agricultural Committee, and also responsible for internal refugees) found a total of 150 Laghmani refugee families (921 people) in the Panjshir. Refugees from Laghman continued to arrive in Darra after this survey was made however, and more refugees have come during 1991.

15.6 Engineer Yar Mohammed told the team this year that an approximate total of 2,000 Laghmani refugees had been recorded in a survey. Of these, approximately 1,000 were described as Mujahideen and therefore ineligible for the shura rations. This leaves about 1,000 civilians requiring rations, that is, about the same number as last year.

15.7 The monitor interviewed a number of Laghmani families in Darra. In addition, he spoke to 28 Laghmanis employed as labourers by an Arab agency to build a clinic near Keraman in Darra-e-Hazara.

15.8 Although the Laghmani refugees face many difficulties, the team concluded that the situation of Salangi refugees (see Section 14) was more urgent. The Shura-e-Nazar's assistance to the Laghmanis has been very important in maintaining them in tolerable conditions. The salangi refugees however have had very little assistance: Given the limited funds available to Afghana dor such emergency assistance, it was concluded that priority should be given to the salangis. 
16.1 The earthquake which struck northeastern Afghanistan in ". February 1991 did considerable damage in the Panjshir valley, destroying or damaging many houses and killing livestock. The Shura-e-Nazar asked Afghanaid if emergency assistance might be available to help those families who had been worst affected by the earthquake.

16.2 A detailed survey of the earthquake damage was made oy the Shura-e-Nazar. The 1 ist of those affected is available from the local authorities in the Panjshir. The Afghanaid field team in the valley reported in April 1991 that three people and 45 domestic animals had died and 312 houses had been partially damaged or totally destoyed as a result of the earthquake.

16.3 Considering the current housing situation in the Panjshir and Afghanaid's policy of 1 imiting handouts of emergency money, which are generally unproductive in the longterm, it was concluded that cash assistance to a relatively small number of earthquakeaffected families would be of 1 ittle longterm value when so many of the valley's houses are already lying in ruins. (See Paragraph 3.15.)

16.4 Available funds would be more usefully applied to prciects, such as the timber tree project (see sections 4 and 7 ), which assist the overall housing problem.

\subsection{CONCLUSIONS}

17.1 The overall situation of the Panjshir valley contiried to improve through 1991, with the resettlement of refugees and rebuilding of houses progressing at a gradual, but steady rate.

17.2 The greatest single problem remains the housing situation. The already high cost of rebuilding houses has been increased particularly by the general scarcity, and hence great expense, of roofbeams. Nevertheless, the number of shops sel1ing roofbeams in Gulbahar and other bazaars has increased markedly since 1990.

17.3 The timber tree cuttings from the nursery set up in 1991 should be distributed in 1992, in order to re-establish smaller nurseries along the valley. They should also be used on the banks of irrigation channels and for general distribution to farmers.

17.4 In order to facilitate the re-establishment of fruit trees as a viable economic concern, a fruit tree nursery should be set up in 1992 as a feeder for the valley. A general distribution of fruit tree cuttings would also be a valuable input.

17.5 The wheat production. in the valley is being ser ously reduced, due to disease in the local wheat varieties having secome of economic significance. Further inputs of improved, disease resistant, seed varieties with the corresponding quantities of 
fertiliser would greatly improve the yields achieved and the economic viability of the wheat crop.

17.6 The severe weed infestation of the wheat crops is both reducing the yields by an economically significant level and resulting in poor quality stocks of multiplied seed. The weed with the most serious economic impact on the crop is wild oats. It is suggested that a chemical control programme for wild oats be considered in 1992 .

17.7 The availability of farm machinery at present is inadequate. This has resulted in dependence on 1 imited human and animal resources, when these are required for other activities. The provision of mechanical threshers would release a large proportion of these resources for cultivation purposes. Mecranical self-powered reapers could also be considered for this purpose.

17.8 Further assistance with the cleaning and repair of irrigation channels is recommended where it will enabie the cultivation of abandoned fields and encourage the return of refugees. Astana village, Sahib channel (Rahmankhel), and Qazikhel and Darzaknel channels (Rokha) should be given priority in this irrigation work.

17.9 If money is available for projects to improve the valley's communications infrastructure, the construction of small bridges at Rokha and Tawakh is recommended, with priority being given to Rokha.

17.10 A further infrastructure project which would assist warwounded and other civilian and Mujahideen patients at Rokha Hospital is the provision of a piped supply of clean water to the hospital. If Afghanaid decides this project does not 1 ie within its terms of reference, the matter should be taken up with an appropriate agency in Peshawar.

17.11 Emergency food assistance is recommended for the pooiest of the Salangi refugees in the Gulbahar and Jabal Saraj area. This assistance should be provided in kind in a programme similar to that organised for Laghmani refugees in 1990. A cash- or food-forwork project to make improvements to irrigation channels on the Shutul river should be considered when further details of the suggested improvements are received from the construction Committee.

17.12 Emergency assistance for Laghmani refugees in the Panjshir is not considered a priority for Afghanaid as the Shura-e-Nazar is providing substantial assistance to them.

17.13 Assistance to those affected by the earthquake of early 1991 is not considered appropriate, as Afghanaid can give wider assistance through projects aimed specifically at alleviating the housing problem, such as improving the supply of timber through timber tree nurseri,es. 


\section{SAMPLE PRICES IN GULBAHAR BAZAAR}

The following prices were recorded in Guibahar bazaar on 8 August 1991. (One seer is equal to $7.07 \mathrm{~kg}$.)

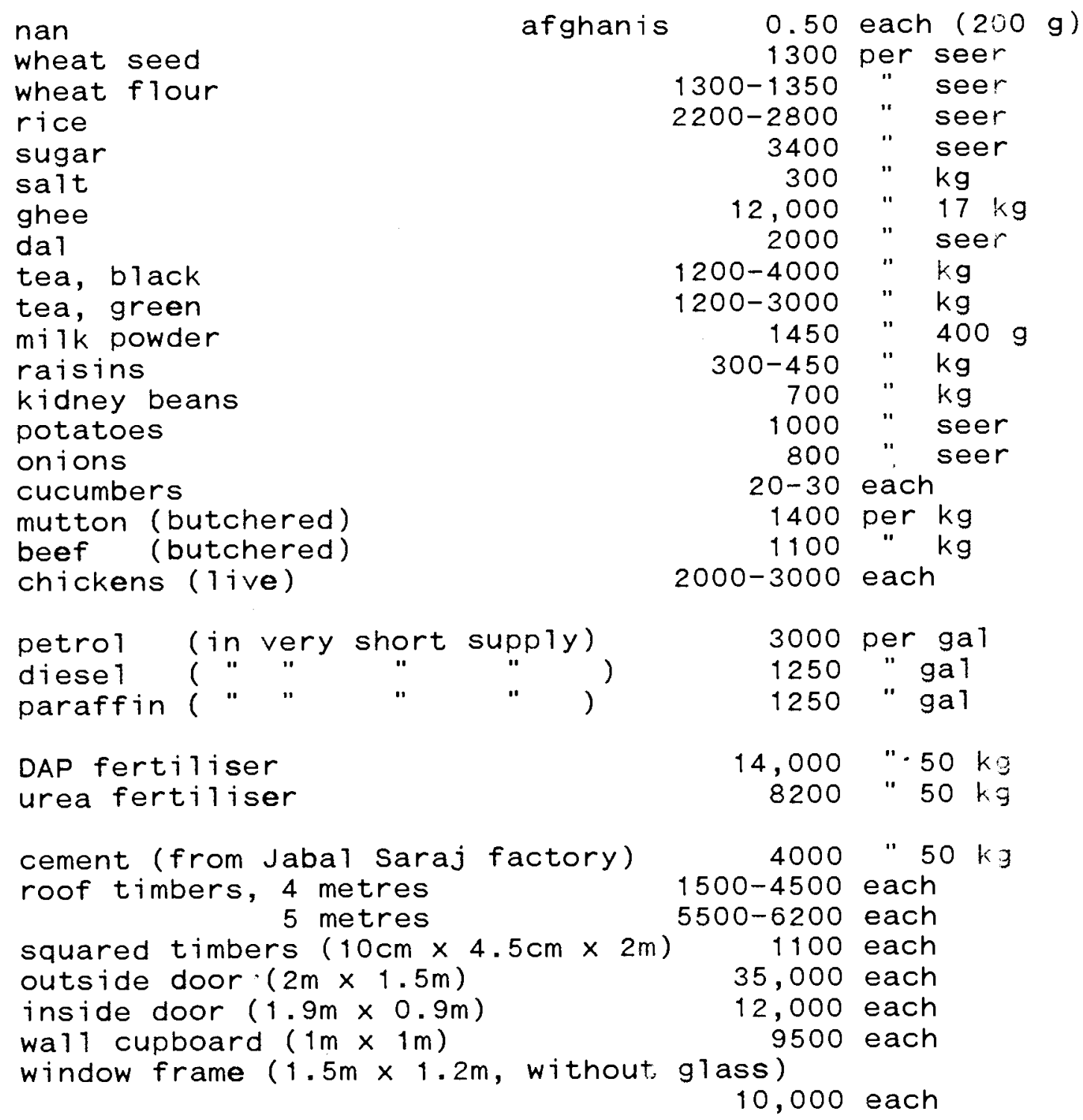

